\title{
N2 GRASSLAND ASSOCIATION: OVER 50 YEARS OF COMMUNICATION IN GRASSLAND FARMING
}

\author{
D.R. Woodfield and J.F.L. Charlton \\ Grasslands Division, DSIR, Palmerston North
}

\begin{abstract}
The New Zealand Grassland Association (NZGA) was formed in 1931 and since then has held 50 annual conferences and provided a forum for the discussion of agricultural problems and the latest research findings $A$ membership of almost 1500 makes it one of the largest organisations of its kind in the world and the annual proceedings is distributed to members in over 40 countries.

This paper reviews the history of the NZGA, its achievements, goals and possible future directions.
\end{abstract}

Keywords: New Zealand, communication, grassland farming

\section{INTRODUCTION}

The New Zealand Grassland Association (NZGA) has, for the past 57 years, provided a valuable forum for farmers, researchers, advisers, educators and commercial people (Table 1) to discuss agricultural problems and the most recent research findings. It is the largest organisation of its kind in New Zealand. The main role of the Association is to facilitate effective communication of research results, experiences, new developments and possibilities to everyone involved in the improvement of the NZ grassland industry. The annual proceedings is distributed to members in over 40 countries.

Except for the war years conferences have been held annually throughout the length and breadth of NZ (Fig. 1). Also, two special conferences on herbage seed production and cultivar use, and the 7th International Grassland Congress (Palmerston North 1956), have been organised. On the occasion of the 50th Annual Conference a review of the history of the NZGA is timely. The Association's first 23 years were reviewed by Stephen Saxby in the 1955 proceedings, although few of these are now in circulation.

THE EARLY YEARS, 1931-1947

In January 1931, AH. Cockayne (then Assistant Director-General of Agriculture) called a meeting to discuss "the betterment of research, investigation, demonstration or instruction in grassland management" (Saxby 1955). Attending were 21 representatives of the Departments of Agriculture and Scientific and Industrial Research, Lincoln College, Massey College, Cawthron Institute and fertiliser companies.

A committee was set up to report on ways to improve co-operation and co ordination in grassland research. This committee recommended "the formation of an association or institution of workers in all departments of grass farming advancement" and organised the inaugural meeting of NZGA in August 1931. The 28 foundation members included such renowned names as Cockayne, Levy, Hudson and Peren, and 23 years later, 11 of these were still members (Saxby, 1955). The last link with the association's formation ended when Sir Bruce Levy died in November 1985. 
Table 1: Sector composition of membership (\%)

\begin{tabular}{lccccc}
\hline & 1950 & 1969 & 1976 & 1961 & 1966 \\
\hline Farmers & 33 & 46 & 59 & 52 & 50 \\
Research and University & $45^{\star}$ & $37^{\prime}$ & 25 & 21 & 25 \\
Advisory & 12 & 16 & 16 & 14 & 11 \\
Commerce & 0 & 0 & 9 & 12 & 9 \\
Students & 10 & 1 & 1 & 1 & 4 \\
Others & 266 & 540 & 600 & 1022 & 1450 \\
\hline Total Number of Members & &
\end{tabular}

- Research, university and advisory

The Association struggled during the depression of the early $1930 \mathrm{~s}$. The second conference, in August 1933, was notable for several reasons:

(1) The President (AH. Cockayne) broadcast his address from his sick bed in Wellington to the conference in Christchurch.

(2) It was the first conference attended by farmers, and at which a farmer paper was presented

(3) It was the first of very few occasions when the NZGA acted (unsuccessfully) as a pressure group (Saxby 1955).

The NZGA was formed when the economy was extremely depressed, with low prices for primary products, but also when interest in research and advice about grassland farming was increasing, particularly in the gumlands of Northland, the Central Plateau pumice land, the Canterbury plains, and the rolling, cold clay downs of Otago and Southland (Saxby 1955). The problems of developing and intensifying grassland farming in these areas were at the heart of many papers presented in this early period; central themes were research into strains of pasture plants, topdressing and management, at a time when these areas of research were just beginning.

During the 1930s the general format of the annual conference was developed, alternating between Palmerston North and Christchurch until 1937, when the conference began visiting all regions (Fig. 1). This decision had a major influence on the growth of the association and the retention of members, particularly farmers in more distant areas.

AH. Cockayne was the driving force behind the inception of the NZGA and, as its first President (from 1931-48) and also its first honorary member, in the early direction of the association. The final statement of his Presidential speech in 1947 still reflects the aims and goals of the NZGA 40 years later: ". . . that there should be the closest possible and intimate relationship of the grassland farmer, the extension worker and the research worker - all working to the same end, the betterment of New Zealand grassland.. " (Cockayne 1947). War.

The NZGA went into recess from 1940-1946 because of the Second World

\section{THE MIDDLE AGES 1948-I 975}

In 1947 the NZGA re-formed and held a conference. Cockayne's 17-year term as President ended in 1948 and the office of President then formally became an annual appointment (Table 4). The NZGA became an incorporated society in 1950, reflecting its more permanent standing and increasing membership.

Membership then grew rapidly (Fig. 2) and over 800 people attended conferences in the early 1950s. These attendances have never been bettered. In the early 1950s aerial topdressing was introduced and meat and wool prices were 


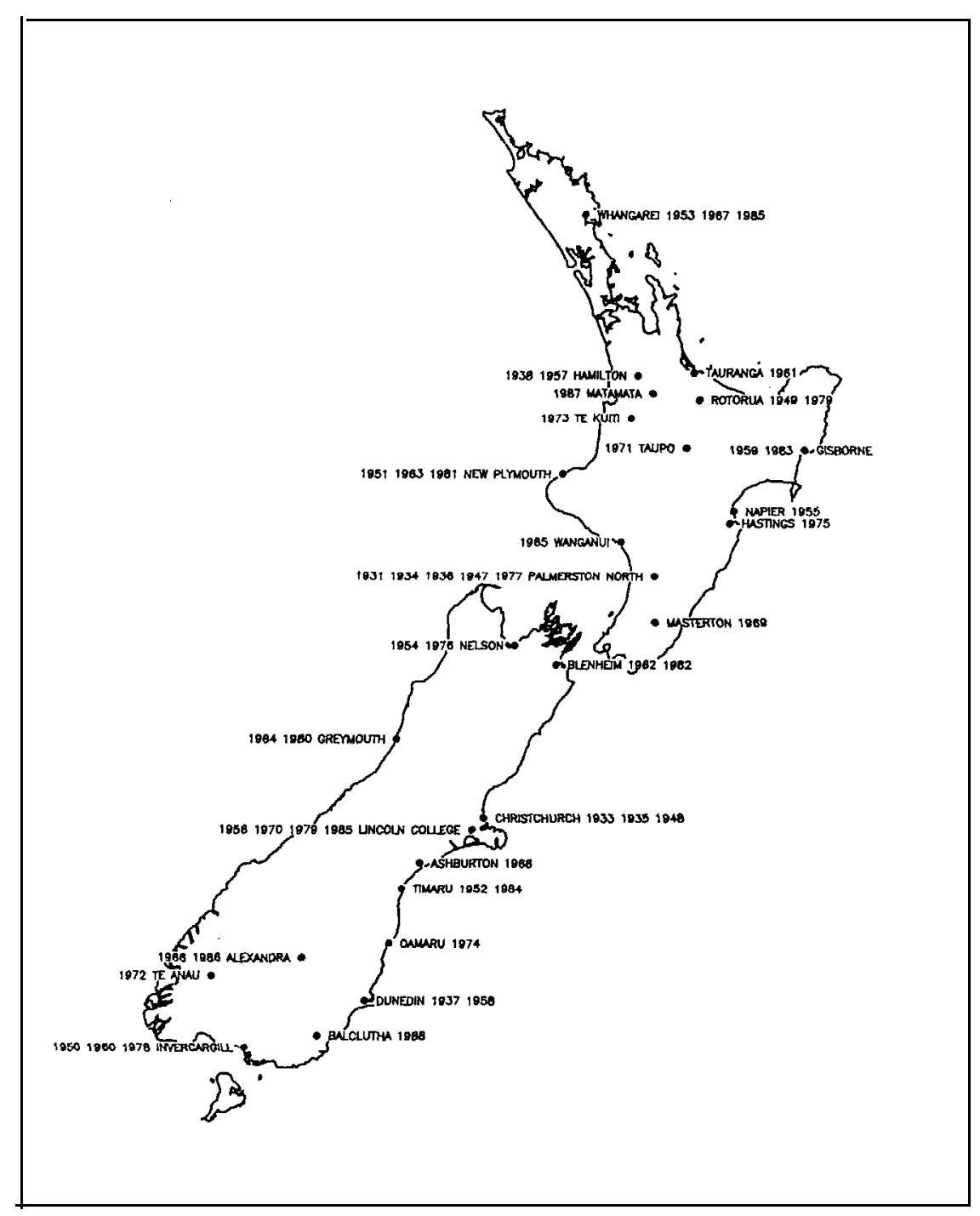

Figure 1: NZGA annual conference location8 1931-I 988.

high $-\mathrm{NZ}$ farming was growing and progressing rapidly. Membership peaked at 784 in 1954 but then gradually declined. Between 1958 and 1975 membership only once exceeded 600 and reached a low of 400 in 1971. Conference attendances in this period were generally 200 to 300 .

Undoubtedly the buoyant economy of the late 1950s through to the 1970s created some apathy towards agricultural research, which may have contributed to declining membership and interest, although the Association maintained a high profile. Manpower certainly limited the Association's development. For most of this period, all the day-to-day running of the Association was left with Mrs Hazel Foster 
(Table 5) who, in addition to her fulltime job with the Department of Agriculture, was Secretary/Treasurer/Editor and often played a major role in organising the annual conferences. The division of these roles from the mid 1970s enabled a far greater range of activities and services to be provided.

A successful conference formula. consisting of two days of spoken papers and a field day, was developed and maintained.

A 35-minute documentary, "Carpet of Grass", premiered at the 1954 Conference. Pacific Film Productions Limited produced the film under the auspices of the NZGA and it was funded by major commercial sponsorships. The idea for making a film of NZ grasslands originated with Mr F.R. Callaghan (President 1949). A committee of Dr W.M. Hamilton (DSIR), Mr H.B. Martin (Grain, Seed and Produce Merchants Federation), Mr H. Woodyear-Smith (Fertiliser Companies rep resentative), Mr T.G. Tyrer (NZ Dairy Exporter) and Mr S.H. Saxby (NZGA) coordinated the film's content and production. "Carpet of Grass" was shown on the national cinema circuit in NZ and the United Kingdom and received very good reviews. Several copies were also sold to overseas interests in the UK, Australia, Uruguay and Kenya Unfortunately the NZGA no longer has a copy, although the National Film Library does.

The best paper award was begun in 1955 to encourage better presentation of spoken papers. On the death of Mr AC. Hurst (Table 6) in 1966, a bequest of $£ 50$ per annum for 5 years was set aside as a prize for the best spoken paper. After 1971 this prize was maintained through sponsorship. All papers during this period were presented orally.

Not until 1958 did a woman present a conference paper, and the boat was well and truly rocked when, in that year, Ms S. MacLean was given the best paper award.

In the mid-late 1960s the conference proceedings was translated into Spanish for distribution in Uruguay under an agreement with a Uruguayan publishing firm.

\section{RECENT TIMES, 1975-I 988}

From 440 in 1975, membership has more than trebled, reaching record levels every year since 1980 (Fig. 2). Even during the hard economic times since 1986 membership has been high because of major efforts by the Executive Committees to:

- rationalise the Association's activities;

- try new ideas;

- strongly publicise the Association;

- encourage commercial companies to participate in the annual conferences; and

- highlight major problems in grassland farming of the region being visited by the conference.

A willingness to try new ideas such as poster sessions (first implemented Greymouth, 1980), forums (Blenheim, 1982) and workshops (Balclutha, 1988), and concurrent sessions (Matamata, 1987), has ensured vibrant communication of information through the annual conference. While the general format of the Conference has been maintained, the use of split field days, where appropriate, has increased flexibility and enabled the major conference themes to be reinforced, by use of the afternoon field trip to concentrate on regional themes covered in the morning sessions. The readiness to use new types of venue, such as the Matamata Racecourse and Telford Farm Training Centre (Balclutha), along with farm hosting to augment motel accommodation, has enabled the annual conference to be held at venues not previously considered.

The number of papers published in the annual proceedings has doubled in the last two decades (Fig. 3). Initially, papers not presented at the conference appeared 


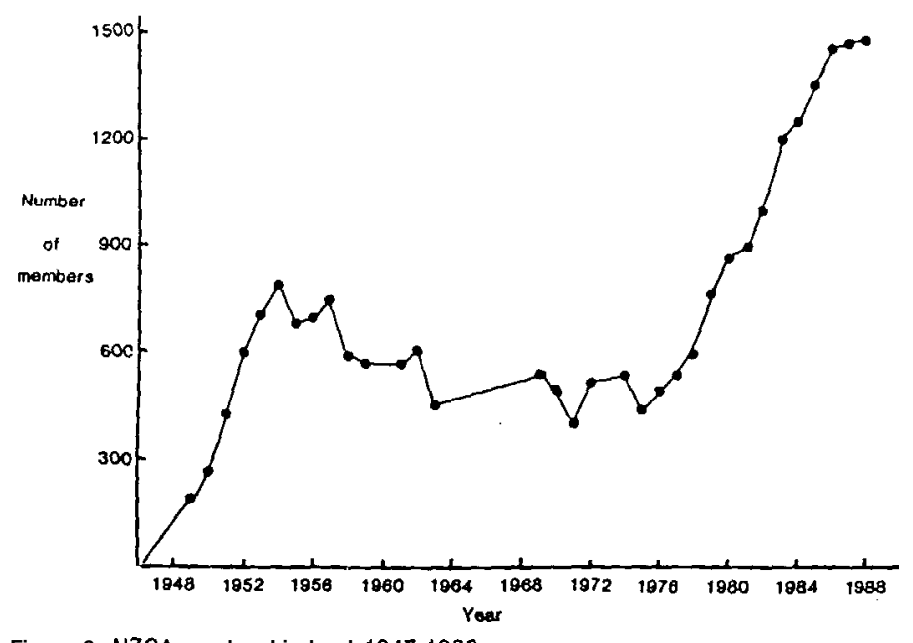

Figure 2: NZGA membership level 1947-1988.

in an extra publication, but in the 1980s posters and concurrent sessions enabled all published material to be presented. Also, Herbage Seed Production (1979), Using Herbage Cultivars (1985). Producing Herbage Seeds (1985) and the reprint book Intensification of Hill Country Farming (1984) have been published as the Association has sought to ensure effective communication of information in specific areas. Furthermore, the introduction of a conference digest of popular summaries since 1981 has proved popular both for conference participants and the media, and has stimulated discussion and public awareness of conference topics. An editorial panel has enabled the Editor to handle the increased number of papers. In the past two years the Proceedings has been translated into Japanese as part of an agency for the NZGA members in Japan.

Publicity campaigns in recent years have improved industry awareness of the Association. Circulation of press releases to the media, interviews on rural radio and advertisements of NZGA publications and conferences have all played a pat-t in increasing membership.

Commercial sponsorship has been essential to keep the cost of conference attendance at a level that does not deter attendance, particulary by farmers.

Since 1975, conference attendances have been consistently around 400 and new members have retained their membership long after the conference has visited their region. Of the members in 1959 (Anon. 1959), 15\% were still members in 1986, representing a solid base of continuing support which has enabled the NZGA to flourish in the past decade. The role of the conference in increasing membership is illustrated by recruitment figures (Table 2), the greatest proportion of these being farmers. The broad cross section of the membership right from the beginning has been a dominant factor in the success of the Association.

Another importart source of new members has been the universities. Twenty percent of new members joining between 1982 and 1988 were students (Table 3). At any particular time only $4-6 \%$ of members are students, but the retention of these members as they move into various professions has increased total membership. The lower subscription rate for students has encouraged them to join and become interested while at university. Almost all student members come from the Lincoln College Plant Science Department or the Agronomy Department at Massey University. Further gains can probably be made from students whose main interests 
Figure 3: Average number of papers per year presented at the annual conferences.

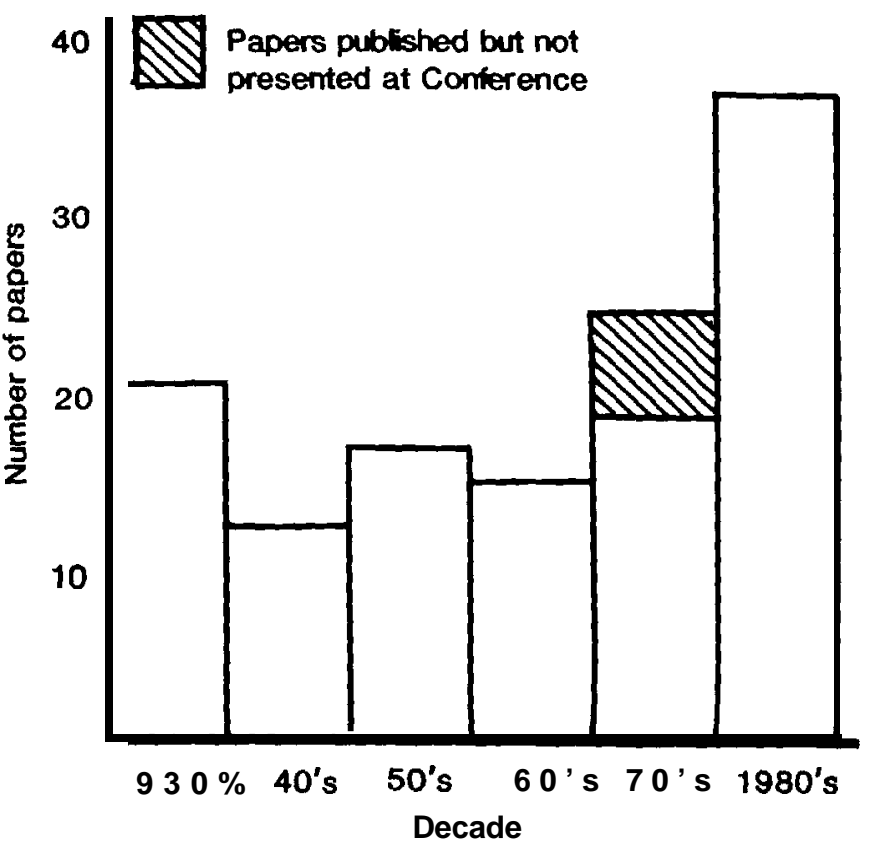

lie in other areas, particularly farm management, animal science and soil science.

Only $39 \%$ of new members over $1982-88$ were farmers (Table 3 ), yet the proportion of farmer members (1986) has been maintained at $50 \%$ (Table 1), indicating that many of the student members continue into the farming sector. The proportion of advisory and extension members has decreased (Table 1), although their total number has increased. More members should be recruited from this profession because of their importance in agriculture. The research and university section of the Association has increased in real numbers but remained fairly constant as a percentage of total members $(21-25 \%)$.

A large membership enables the Association to remain financially solvent, which in turn greatly increases its range of activities, and also helps promote more communication of research and experience generally throughout the research and farming communities.

The workload associated with 1500 members has been met only through obtaining casual assistance in the form of a Publications Officer, an Assistant Secretary and help for the Treasurer.

The Grassland Association has survived many pitfalls, both financial and political. Many times in its history various government departments have threatened to boycott the annual conference, sometimes because of executive policy, others because of the venue chosen for the conference (particularly isolated venues) and also because of the economic position. That it has been possible to avoid these pitfalls has been, in major part, due to the composition of the Executive Committee, which has always had a good balance of farmers, researchers (both MAF and DSIR), commercial representatives and university staff.

\section{PAST-PRESIDENTS AND OFFICE BEARERS}

Many of those who have served on the Executive of the Association, particularly the Presidents (Table 4), have been outstanding in the improvement of New 
Table 2: Recruitment of new members at conferences since 1975

\begin{tabular}{llr}
\hline Year & Venue & No. of new members \\
\hline 1975 & Hastins & 6 \\
1976 & Nelson & 40 \\
1977 & Palmerston North & 34 \\
1978 & Invercargill & 123 \\
1979 & Rotorua & 25 \\
& Christchurch & 23 \\
1980 & Greymouth & 64 \\
1981 & New Plymouth & 95 \\
1982 & Blenheim & 60 \\
1983 & Gisborne & 77 \\
1984 & Timaru & 83 \\
1985 & Christchurch & 17 \\
& Northland & 77 \\
1986 & Alexandra & 56 \\
1987 & Matamata & 102 \\
\hline
\end{tabular}

- Special herbage seed and cultivar use conferences

Table 3: Number and percentage of new members joining between January 1982 and July 1988 in each occupational class

\begin{tabular}{lcc}
\hline Occupation & Number & of new members \\
\hline Farmers & 390 & 39 \\
Advisory & 88 & 9 \\
Research & 156 & 15.5 \\
University staff & 37 & 4 \\
Students & 197 & 20 \\
Commerce & 115 & 11.5 \\
Others (e.g. MPs) & 10 & 1 \\
\hline & 993 & 100 \\
\hline
\end{tabular}

Zealand grassland farming, but to single out individuals would be unfair.

The office bearers (Table 5) are less well known but the success of the Association is in no small part due to their efforts. R.P. Connell, in particular, contributed greatly in the early years and but for his untimely death in 1948 would have had further recognition for his efforts.

\section{Honorary Life Members}

The NZGA has honoured 17 members with life membership (Table 6) for outstanding service to the Association. In particular Mrs Hazel Foster's service from 1952 (as assistant to Messrs Saxby, Glue and Scott) and from 1957-I 973 as Secretary, often at great personal cost, is in our view worthy of special praise. The gold clock presented at the Te Kuiti Conference in 1973 still has pride of place on Mrs Foster's mantelpiece.

\section{GRASSLAND ASSOCIATION AND GRASSLAND MEMORIAL TRUST AWARDS}

At the AGM in 1957, the first award (a citation and f50) for an outstanding contribution to the betterment of New Zealand grassland was presented, to $S$. Saxby. H. Woodyear-Smith (1958), C.J. Hamblyn (1959), G.B. Baker (special award 1959), P.W. Smallfield (1961), AH. Cockayne (1962) and L. Corkill (1963) were later recipients. The presentation to Mr Hamblyn was one of the saddest and most unusual events in the Association's history. Afer thanking the Association Mr 
Table 4: past-Presidents of the NZGA

\begin{tabular}{llll}
\hline $1931-1948$ & AH. Cockayne $\dagger$ & 1969 & R.H.M. Langer \\
1949 & F.R. Callaghan $\dagger$ & 1970 & R.W. Brougham \\
1950 & P.W. Smallield $\dagger$ & 1971 & N.A Cullen \\
1951 & Sir E.B. Levy $\dagger$ & 1972 & B.R. Watkin \\
1952 & R.H. Bevin & 1973 & J.G.H. White \\
1953 & AW. Hudson $\dagger$ & 1974 & C. During \\
1954 & G.A. Holmes & 1975 & G.L. Banfield \\
1955 & J.F. Filmer & 1976 & AW. Hurst \\
1956 & J.W. Calder & 1977 & W.G. Thurston \\
1957 & S.H. Saxby & 1978 & R.S. Scott \\
1958 & L. Corkill & 1979 & AJ. Harris \\
1959 & C.E. Iverson & 1980 & T.E. Ludecke. \\
1960 & P.D. Sears & & J.A. Lancashire \\
1961 & J.W. Woodcock $\dagger$ & 1981 & J.A. Lancashire \\
1962 & I.L. Elliot & 1982 & J.A.H. Inglis \\
1963 & H. Woodyear-Smith & 1983 & M.R.J. Toxopeus \\
1964 & T.W. Walker & 1984 & AJ. Cresswell \\
1965 & AT. Johns & 1985 & G.W. Sheath \\
1966 & AR. Dingwall & 1988 & A.C.P. Chu \\
1967 & G.S. Robinson & 1987 & J.F.L. Charlton \\
1968 & J.P. Lambert & 1988 & M.L. Smetham \\
\hline
\end{tabular}

$\uparrow$ Founding members

- Died during Presidential term

Table 5: NZGA office bearers 1931-I 988

\begin{tabular}{|c|c|c|c|}
\hline Secretary & Treasurer & Editor & \\
\hline \multicolumn{4}{|l|}{$\begin{array}{l}\text { 1931-48 R.P. Connell } \dagger \\
\text { 1948-54 S.H. Saxby } \dagger \\
\text { 1954-55 D.I. Glue } \dagger\end{array}$} \\
\hline $\begin{array}{l}\text { 1955-57 R.H. Scott } \dagger \\
\text { 1957-73 Mrs H.N. Foster } \dagger\end{array}$ & & 1968-78 & W.G. Thurston \\
\hline 1973-77 AC. Burgess & 1976-77 M.J. Hill & & \\
\hline $\begin{array}{l}\text { 1977-81 H.J. Bezar } \\
\text { 1981-84*J.F.L. Charlton }\end{array}$ & $\begin{array}{l}1977-80 \text { E. Roberts } \\
\text { 1980-83 A.C.P.Chu }\end{array}$ & $1978-85$ & J.L. Brock \\
\hline $\begin{array}{ll}\text { 1984-87 } & \text { D.R. Woodfield } \\
\text { 1987- } & \text { P.W. Theobald }\end{array}$ & $\begin{array}{l}\text { 1983-86 P.M.P. Matthews } \\
\text { 1986- P.A. Kemp }\end{array}$ & $\begin{array}{l}1985-87 \\
1987-\end{array}$ & $\begin{array}{l}\text { R.E. Burgess } \\
\text { M.J. Baker }\end{array}$ \\
\hline Publications Officer. & 1981-Mrs P. Charlton & & \\
\hline
\end{tabular}

$\dagger$ Secretary/Treasurer/Editor

Changeover was April 1981 rather than the usual November date

Table 6: Past and present Honorary Life Members of NZGA

Year elected

Year elected

\begin{tabular}{lclc} 
& Year elected & Year elected \\
\hline AH. Cockayne & 1948 & J.P. Lambent & 1976 \\
Sir E.B. Levy & 1951 & R.W. Brougham & 1978 \\
AW. Hudson & 1952 & H.S. Gibbs & 1979 \\
S.H. Saxby & 1954 & AW. Hurst & 1981 \\
AC. Hurst & 1960 & B.A. Watkin & 1982 \\
Mrs H.N. Foster & 1968 & N.A. Cullen & 1983 \\
L Corkill & 1969 & J.A.H. Inglis & 1984 \\
H. Woodyear-Smith & 1971 & J.G.H. White & 1988 \\
W.G. Thurston & 1974 & J.A. Lancashire & 1988 \\
\hline
\end{tabular}

Hamblyn, on returning to his seat, suffered a fatal heart attack (Anon 1959). A special general meeting had to be called several months later to conclude the business of the 1959 AGM.

After the formation of the Grassland Memorial Trust in 1963, the Grassland 
Association award was phased out; since then the Trust has made awards for outstanding contributions to New Zealand Grassland farming. The Trust was set up initially to honour the work of Sir George Stapledon and Dr P. Sears, although AH. Cockayne, Sir E.B. Levy, R.A Candy, C.P. McMeekan and L. Corkill have also been honoured.

\section{LOCAL ORGANISING COMMITTEE}

In addition to the National Executive, enthusiastic volunteers from the host region work on the local organising committee (LOC) which is formed approximately 18 months before each conference. The LOC helps to set the conference themes each year and manages local organisation and publicity. Without an active LOC the NZGA would find it very difficult to operate. On the few occasions that communication between these two committees has been poor, the annual conference has been less successful. In general, however, communication and cooperation are excellent and ensure that the regional emphasis of the conference is maintained.

\section{THE FUTURE}

The move to "user-pays" policies in government departments such as DSIR and MAF has already affected the traditional approach to organising and running annual conferences. Voluntary work on local organisations has declined somewhat because of severe financial limitations on departmental expenditure.

Sponsorship of the annual conference is now harder to obtain. However, commerce is keen to pay for advertising space at the conference and in the proceedings. The commercial display area is now an attractive feature, staged in a separate area from the technical poster displays. Advertisements in the proceedings, which first featured during the $1960 \mathrm{~s}$, have been re-introduced. Such commercialisation of the annual conference is being developed carefully, and provided it is fair to all participants, should maintain the viability of NZGA activities.

As contract research for revenue earnings becomes established in research institutions, the type and format of papers offered at annual conferences may change. Restriction on the publication of some research results, because of commercial sensitivity, may mean that offered papers are discussion documents rather than complete presentations of data. There has been no shortage of offered papers to date, but the National Executive Committee is aware of such possibilities, and is prepared to develop the level of discussion by encouraging participation of attenders. The 1988 Conference in Balclutha features a workshop session on outof-season lamb production, and this format will ensure small-group discussion with conclusions reported to the conference.

Young Farmers Club involvement in the NZGA should be encouraged as direct contact with these clubs has been small since the 1940s. Attracting University students from non-traditional sources should also augment current membership.

Development of farm hosting accommodation for visitors has recently enabled the annual conference to be held in regions not previously visited, such as Matamata and Balclutha We envisage that this approach should open up plenty of suitable venues for future conferences in centrally located regions, which will reduce travel expenses. This should help the Association to maintain and develop its objectives during the years ahead.

Despite current problems in the pastoral industry, New Zealand's economy will continue to depend on efficient grassland farming. The NZGA will continue to promote new developments and so help ensure that New Zealand grassland farming remains efficient, competitive and progressive. 


\section{Acknowledgements}

Mrs H. Foster Mr S. Saxby, Dr. R. Brougham and Mr W. Thurston for assistance with background information.

\section{References}

Anon 1959. List of elected members as at 31 May 1959. Proceedings NZ Grassland Association 21: 145-48.

Anon 1959. Association's award for betterment of grasslands Proceedings NZ Grassland Association 21: 138-

$$
139 .
$$

Cockayne, AH. 1947. Presidential address. Proceedings NZ Grassland Association 9: 1-7.

Saxby, S.H. 1955. The New Zealand Grassland Association. Proceedings NZ Grassland Association 16: 24-34. 